\title{
Machine or Melody? Joseph Ratzinger on Divine Causality in Evolutionary Creation
}

\author{
MATTHEW J. RAMAGE \\ Benedictine College, United States \\ mramage@benedictine.edu \\ ORCID: 0000-0001-7370-7531
}

\begin{abstract}
In a document penned under the direction of its then-president Cardinal Joseph Ratzinger, the Vatican's International Theological Commission observed that many neo-Darwinian materialists and their Christian critics share a misunderstanding of the nature of divine causality. This article explores the thought of Joseph Ratzinger in view of proposing the features of a path that seeks to eschew these faulty understandings of how God causes evolutionary change within our world, thus providing an alternative to the Intelligent Design movement's approach to creation. . Ratzinger has a deep respect for the integrity of nature, rejecting the notion that God is a "craftsman" who "tinkers" with the world. According to Ratzinger, evolutionary change occurs "precisely in the processes of a living being" even as human beings are "not the mere product of development." Finally, the emeritus pontiff insists that creation is an ever-present act that unfolds "in the manner in which thought is creative", a dynamic that he describes variously as a story, drama, melody, and symphony. Wedding these and other key insights, this article submits that Ratzinger's thought on evolution should lead us to conceive of creation less along the lines of an intelligently designed machine and more as a masterpiece story that is continually being told as its plot unfolds naturally over the course of time.
\end{abstract}

Keywords: Ratzinger; evolution; creation; science; faith.

ScientiaetFides $8(2) / 2020,307-321$ 


\section{Introduction}

In a document penned under the direction of its then-president Cardinal Joseph Ratzinger, the Vatican's International Theological Commission observed that many neo-Darwinian materialists and their Christian critics share a misunderstanding of the nature of divine causality (International Theological Commission 2004, §69). In this article, I will explore Joseph Ratzinger's thought in view of proposing the features of a path that seeks to eschew these faulty understandings of how God causes evolutionary change within our world, thus providing an alternative to the Intelligent Design movement's approach to creation.

Ratzinger has a deep respect for the integrity of nature, rejecting the notion that God is a "craftsman" who "tinkers" with the world. According to Ratzinger, evolutionary change occurs "precisely in the processes of a living being" even as human beings are "not the mere product of development." Finally, the emeritus pontiff insists that creation is an ever-present act that unfolds "in the manner in which thought is creative," a dynamic that he describes analogously as a story, drama, melody, and symphony. Wedding these and other key insights, I will conclude by submitting that Ratzinger's thought on evolution should lead us to conceive of creation less along the lines of an intelligently designed machine and more as a masterpiece story that is continually being told as its plot unfolds naturally over the course of time.

\section{The Role of Contingency in Evolution and the Debate Concerning God's Role in It}

Any satisfactory account of divine causality within evolution must seek to address the role that contingency or randomness plays within the world. For one reason or another, many people believe that divine providence is incompatible with an evolutionary process driven in large part by natural selection and random genetic variation. Indeed, materialists frequently base their rejection of God on this supposed incompatibility-that chance and purpose are mutually exclusive-in other words, that a system driven by 
chance has no room for God. Meanwhile, many Christians are attracted to the approach of the Intelligent Design ID movement (hereafter ID), which replies to this argument by seeking steps in the history of evolution that cannot be explained by pure chance. They point to the great unlikelihood that each of the 'chance' events that were necessary to bring about the various stages of life on earth could have come about through 'merely' natural processes, i.e., in the absence of a higher power who arranged things just so that astoundingly complex structures would arise over time. In ID language, these marvels are said to exhibit "irreducible complexity," (hereafter IC). A few examples of such complexity that ID advocates believe to require the direct intervention or unique planning of a divine designer include eyes, wings, and the bacterial flagellum. ${ }^{1}$

Unlikely as it may have been for such structures in nature to have evolved as they have, a number of scientific works have rebutted claims regarding their allegedly IC nature. ${ }^{2}$ More relevant to the present work, though, is the fact that the doctrine of creation within the Christian tradition has always been approached at a far more fundamental level than what lies in the sights of those who seek God through this or that instance of complexity within the world (see White 2017, 88-89). The classical Catholic tradition points to God as the source of being for all things that exist, he who continually creates and sustains all that exists, including the development and evolution of forms within the cosmos. ID, on the other hand, shies away from this classic metaphysical approach and tries to make a empirically-grounded case for instances of causal discontinuity or gaps within the order of nature. For his part, Benedict echoes the tradition is describing God as being "too great" to fit into gaps like these (Benedict XVI 2008, 144).

1 Throughout this paper, I will be referring frequently to ID proponents or advocates without further specifying individual authors. While the constraints of this work do not permit me to explain their arguments in further detail, these thinkers share a common approach that can be grasped in the following works: Dembski 2004; Behe 1996; Meyer 2009.

2 For a concise and forceful Thomistic reply to the ID approach, see Austriaco 2019, 183-188; 195-208. For an excellent response to ID from the standpoint of evolutionary biology, see McKnight and Venema 2017, 67-92. And, for a punchy response from the perspective of an atheist biologist, see Dawkins 2009. 
In line with the Catholic tradition at large, the International Theological Commission (hereafter ITC) does not demonstrate much interest in the ID endeavor. The commission does, however, take notice that a growing body of critics focus their efforts against consensus evolutionary theory on seeking out biological structures that exhibit such intricacy that they cannot have arisen through the contingent, random process of natural selection. It then offers the following response to this viewpoint:

Many neo-Darwinian scientists, as well as some of their critics, have concluded that, if evolution is a radically contingent materialistic process driven by natural selection and random genetic variation, then there can be no place in it for divine providential causality [...]. But it is important to note that, according to the Catholic understanding of divine causality, true contingency in the created order is not incompatible with a purposeful divine providence. Divine causality and created causality radically differ in kind and not only in degree (International Theological Commission 2004, §69; see also Aquinas 1981, I, q. 22, a. 4 ad 1).

The ITC insists that divine providence and contingency within creation are not in competition with one another, because the causality at work within each occurs at a radically different order of being. Indeed, they are of such different orders that we must always remain cautious even when envisioning God's causality as occurring as a different kind or on a different plane than that of creatures, for the temptation inevitably arises to picture God as just another, albeit higher, cause within creation.

Another important point that the ITC emphasizes in this regard is that the creaturely causality at work in evolution can only occur because God created and sustains the process in the first place: "[E]ven the outcome of a truly contingent natural process can nonetheless fall within God's providential plan for creation [...]. Divine causality can be active in a process that is both contingent and guided. Any evolutionary mechanism that is contingent can only be contingent because God made it so" (International Theological Commission 2004, §69; see also Aquinas 1981, I, q. 22, a. 2). ${ }^{3}$

3 What the ITC is suggesting here aligns well with what Aquinas has to say about the place of contingent events of chance in relation to God's providence. For a helpful discussion of this topic, see Tabaczek 2019, 445-82. 
It follows from the view articulated here that both neo-Darwinian materialists and their Christian critics are mistaken in thinking that the presence of random genetic variation and natural selection is evidence that the process of evolution is absolutely unguided. In reality, an unguided evolutionary process-one that falls outside the bounds of divine providence-could not exist in the first place for the very reason that nothing can exist apart from the will of God. It turns out, then, that the phenomenon of chance's causal role in our world is itself willed by divine design. Or, as Michael Dodds, O.P. puts it, "God's causality acts precisely through the 'non-causality' of chance $[. .$.$] through the indeterminism of nature in its very indeterminism"$ (Dodds 2017, 220). ${ }^{4}$

\section{God Works through the Natural World, not "Next to" Its Evolutionary Processes}

Having discussed the issue of contingency's role within creation according to the Catholic tradition as distinct from the approach taken by the ID movement, we may now turn directly to Joseph Ratzinger's thought on how divine action operates in evolution. Ratzinger's principles will be proposed as a robust alternative to ID and an outstanding resource for carrying forward the Catholic tradition's approach to creation specifically when it comes to the topic of evolution. The emeritus pontiff is well aware that evolution challenges our existing analogies for creative action, and below explore what he proposes as alternatives. First, though, we must acquire a picture of Ratzinger's overall view of the matter at hand.

Ratzinger's approach to divine causality in creation starts with a negative: namely, his insistence that we not conceive of God as creator "according to the model of a craftsman" (nach dem Muster des Handwerkers), in tandem with his emphasis that the creation of man's spirit is "least of all to be imagined as an artisan activity (handwerkliches Tun) of God, who suddenly

4 For an excellent discussion of the word "random" as used in science in contrast with how people sometimes understand the term, see Barr 2016, 54-63. 
began tinkering (hantieren) with the world" (Ratzinger 2011, 141; Ratzinger 1973, 159). The emeritus pontiff wants nothing to do with Deism, nor does he want us to construe God as a machinist who operates in the cosmos along the same plane of being as the rest of creation, occasionally dipping into cosmic processes to keep the engine humming (Favale 2018).

To this, Ratzinger helpfully suggests that the creation of the first human or humans can be understood by looking at what happens in the creation of every human today. It is a marvel, he says, that the infusion of the human soul occurs "not next to" (nicht neben) but rather "precisely in the processes of a living being" (gerade in den Prozessen des Lebendigen), i.e. the biological process by which a sperm and egg come together to form an embryo (Ratzinger 2013, 79; Ratzinger 1989, 68). In Ratzinger's view, despite coming to be "in" the ordinary processes of life, spirit is nevertheless to be understood as the goal of creation and somehow above the rest of it rather than being just another accidental feature of the natural world. This twofold emphasis is captured well when Ratzinger describes the human soul's being 'infused' by God as "just another way of saying that spirit is created and not the mere product of development, even though it comes to light by way of development" (auch wenn er in der Weise der Entwicklung in Erscheinung tritt) (Ratzinger 2011, 141; Ratzinger 1973, 159). ${ }^{5}$

Ratzinger ties together the above principles in deeming it "evident that being-in-movement as a whole (das Ganze der Seinsbewegung) - and not just the beginning-is creation" (Ratzinger 2011, 141; Ratzinger 1973, 158). The emeritus pontiff is emphatic that God's creative activity does not consist in a one-time event of the remote past or even in periodic interventions within history. Rather, he insists that creation is an ever-present act that encompasses all of space and time, including the process of evolution itself.

\footnotetext{
On the subject of humans not merely being the mere product of development, I would like to mention that, even as this article argues against the ID approach to divine interventions within creation, Ratzinger does not reject the notion that God in creating man acted in a special way in comparison to how he operates in the rest of creation. That said, it is decidedly not Ratzinger's view that the created humans independently of natural processes, as the above text indicates. For more on the meaning of man's "special creation" according to Ratzinger, see Ratzinger 2011, 141-42.
} 
Thus, he taught in his 1964 course on creation at Münster that to understand "evolutionary creation" (Schöpfung evolutionistisch) is to understand that creation does not refer to a remote beginning of the world but is rather "a statement that concerns being as such" (eine Aussage, die das Sein als solches betrifft), in other words, "being as temporal and becoming" (das Sein als zeitliches und werdendes).${ }^{6}$ For its part, then, "evolution is [...] simply the understanding of creation in its temporality and in its temporal actuality" (Evolution ist... einfach das Verständnis der Schöpfung in ihrer Zeitlichkeit und in ihrer zeitlichen Eigenwirklichkeit) (Ratzinger 1964, 174; Sanz 2014, 238n122). ${ }^{7}$

Ratzinger does not find evidence of God's existence primarily in the world's beginning, for God is the source of all creaturely being at all timesincluding, as we now know, everything that happens in evolution. Accordingly, Ratzinger writes that God's action in the world must not be thought

6 Just a few years later, he would publish this thought, adding that the biblical account of the creation of the cosmos-and of man-"does not designate a remote beginning" (Ratzinger 2011, 141; Ratzinger 1973, 159). The creation course material cited here derives from the unpublished lecture notes (Vorlesungsmitschriften) from Professor Ratzinger's courses on creation housed at the Institut Papst Benedikt XVI in Regensburg which I have translated from the original German texts. Ratzinger offered three courses on the doctrine of creation (Schöpfungslehre) over the course of his academic career, and I will refer to them here respectively as Schöpfungslehre (1958), Schöpfungslehre (1964), and Schöpfungslehre (1976). The text cited above is from Ratzinger, Schöpfungslehre (1964), 173, while the term Schöpfung evolutionistisch is found in Schöpfungslehre (1964), 122. The German of this text is reproduced in Sanz 2014, 201-48 at 238n122. Informative analyses of the 1964 manuscript along with reproductions from the German originals can be found here as well as in Sanz 2014, 31-70 and Sanz 2014, 453-96. For a survey of his other two courses accompanied by original German texts, see Sanz 2016, 11-44 and Sanz 2016, 251-83. For a discussion of the weight that ought to be accorded these unpublished works with a helpful comparison to the value we duly accord to Aristotle's lecture notes, see de Gaál 2019, 93-120 at 82 .

7 To this, Ratzinger adds, "But this seems to be the real turning point of the Darwinian view of the world-that the factor of time also becomes constitutive, because being is grasped as becoming. Being and time coincide (Sein und Zeit fallen so ineinander), whereas previously only being and space were internally assigned to each other.” Ratzinger 1964, 171; Sanz 2014, 237n119. Observing consonance between this view and Heidegger's classic work Sein und Zeit, Ratzinger stresses that "being and time enter into an inseparable relation" (eine untrennbare Relation) and that "temporality now appears as the essential constitution of being itself (die wesentliche Verfaßtheit des Seins selbst).” Ratzinger 1964, 82; Sanz 2014, 233n104. See also Ratzinger 2011, 138; Ratzinger 1973, 156]: "Being is time (Das Sein ist Zeit), It does not merely have time." 
of in a categorical (kategorial) sense, as one of the categories of this world, but rather in a transcendental (transzendental) sense, that is, insofar as he is "the supporting power in and over the whole" (die tragende Macht in und über dem Ganzen) (Ratzinger 1964, 85; Sanz 2014, 235n112). Or, as he wrote in an article published just a few years after giving this course, evolution operates at the "phenomenological level" (phänomenologischen Ebene), whereas creation occurs at the "ontological level" (ontologischen Ebene) (Ratzinger 2011, 133; Ratzinger 1973, 149). The "dynamic character of being” (dynamische Charakter des Seins) is entirely compatible with creation; and, as a result, Ratzinger writes, "What the believer claims lies outside of the arguments of the biologists," (Was der Gläubige behauptet liegt außerhalb des Streites der Biologen) for it is "a statement about the whole of being as such" (eine Aussage über das Ganze des Seins als solchem).” We are thus authorized to say that the content of the belief in creation (der Inhalt des Schöpfungsglaubens) consists in "the decision of faith to understand the whole as an expression of logos" (Ratzinger 1964, 174; Sanz 2014, 239n123). ${ }^{8}$

\section{Creation Unfolds according to the Manner of Thought}

Ratzinger's holistic view of God's action in the world is expressed most intriguingly when he proposes that creation should be understood as unfolding "in the manner in which thought is creative (in der Weise, in der das Denken schöpferisch ist)" (Ratzinger 2011, 140; Ratzinger 1973, 157-58). As we will discover in a moment based on what he says on the topic elsewhere, this idea is intimately connected with the notion that creation is to be thought of less like a static artifact or a machine that has been intelligently designed and more as a story, drama, or song that is continually unfolding naturally according to its own internal plot or score.

Fascinatingly, these are precisely the images that Professor Ratzinger deployed to explain evolutionary creation (Schöpfung evolutionistisch) in his

8 Without identifying ID specifically, Thomas Joseph White, O.P. ably demonstrates the folly of arguing for God's existence based upon (im)probabilities, that seeking evidence for or against God's existence through the empirical sciences (White 2017, 88-89). 
university courses on the doctrine of creation. In his 1964 course, Ratzinger rejected the view that the creation and conservation of the universe are "separate acts of a two-part drama" (getrennte Akte eines zweiteiligen Dramas), arguing instead that they comprise "a single comprehensive reality" (eine einzige umgreifende Gesamtwirklichkeit) (Ratzinger 1964, 83; Sanz 2014, 234n105).

To drive home this point, he returns to the notion that creation unfolds analogously to the way in which thought is creative by comparing it to a drama, symphony, or "cosmic melody":

God's eternity is the creative consciousness (Gottes Ewigkeit ist das schöpferische Bewußtsein) [...]. If we understand the actuality of the world as a cosmic melody or as a drama (die ganze Weltwirklichkeit als eine kosmische Melodie oder als ein Drama) then we can say that the preservation of the world by God means: being enveloped in this symphony or drama through the presence of the divine spirit” (das Umgriffensein dieser Sinfonie oder des Dramas durch das Präsens des göttlichen Geistes) (Ratzinger 1964, 84-85; Sanz 2014, 235n112).

We find a similar image in Ratzinger's 1976 course on creation held at Regensburg.

The world is not simply the invariant representation of eternal patterns, but rather like the performance of a score (der Vollzug einer Zahlenpartitur), that is, of a structure that can only be played out (Abgespielt) in a process of inner movement in being itself (inneren Bewegung im Sein selbst). Becoming (Das Werden) no longer exists on the surface but penetrates into the concept of being (Seinsbegriff). The movement itself is constitutive. However, the performance of the score is not programmed to the last detail, but occasionally goes wrong (Die Ausführung der Partitur aber ist nicht bis ins Letzte programiert, sondern es geht ab und zu daneben) (Ratzinger 1976, 93; Sanz 2016, 275n3). ${ }^{9}$

9 Of course, we as humans, like the rest of creation, also "go wrong" from time to time. In this regard, I find it interesting that Ratzinger not only emphasizes that the entire creative act is thought, but that this applies to the human being in particular: "Every human being is a thought of God" (jeder Mensch ist ein Gedanke von Gott) (Ratzinger 2002, 181). 
This last text is particularly valuable, as it not only adds a powerful image to our repertoire of analogies for creation but also makes room for an important reality that is inherent to the contingent nature of the evolutionary process: as in the execution of a drama or score, sometimes things go wrong. Mutations happen. Sometimes these lead to suffering and death, while at other times they prove beneficial and carry creation to further perfection. Creation does not merely follow the preprogrammed instructions of a divine craftsman, nor does God "tweak" his story along the way along the lines envisioned by many ID proponents. On the contrary, evolutionary adaptations arise from within the story of creation itself, according to its own internal rules instilled therein by the divine artist.

\section{Which Kind of Rationality Suits the Christian Faith? Which Is the Better Story?}

At the start of his tenure at Bonn University in 1959, newly-minted professor Joseph Ratzinger delivered a lecture that the later cardinal would describe as containing questions that still remained "the connecting thread of my thought" (Ratzinger 2005, 7, my translation). The address, entitled "The God of Faith and the God of the Philosophers: A Contribution to the Problem of a Theologia Naturalis," did not deal specifically with evolution, yet the question posed by the young academic at the outset of his career captures the debate that lies at the heart of how one ought to think about the nature of creation given evolution. The question is: "Which kind of rationality suits the Christian faith?” (Ratzinger 2005, 8, my translation).

I suggest that we re-propose this question in today's evolutionary context along the following lines. If we conceive of evolutionary creation as a story, then consider: Who is the better author or scriptwriter-one whose story cannot advance without resorting to authorial interventions to wriggle his way out of a corner he has backed himself into, or on the other hand the author who crafted his story so tightly that the plot resolves naturally in a way consonant with the story's own terms, following its own internal rules? In everyday life, one of the ways we judge the quality of a novel, a movie, or any other story is precisely 
whether it is able to achieve what the latter author above has done, whereas the first author-who has to insert unnatural deus ex machina interventions into his plot in order to get the story he wants-is correctly seen as cheating.

I find that this analogy of a story is especially well-suited to explain how God works through the internal principles of instrumental causes in the universe. But, of course, we have also seen that another image Ratzinger evokes in this regard is that of the enacted story-i.e., a drama or play. Conveniently, physicist Stephen Barr has developed precisely the sort of image I have in mind in his comparison of God to a playwright with creation as his play (Barr 2016, 57, 181). Like any dramatist, the divine playwright is the cause of the entire play in all its aspects-every character, every event, every word. Barr calls this "vertical causality." At the same time, he continues, it is also true that within the play there is true "horizontal causality" as its plot has an internal integrity in which things truly cause one another in accordance with the story's own rules as envisioned in the playwright's plan (For example, Ophelia ultimately kills herself because Shakespeare makes her do it, but also because of how Hamlet treated her). Within this play, the causality of the playwright and that of the characters in his plot are not in competition with one another but rather occur in different orders of reality, an observation that Barr himself connects with the traditional distinction between primary and secondary causality.

Applying this analogy to concrete created things, it is idle to ask whether a given creature exists because it evolved or because God created it, whether a feature of it exhibits IC and is thus evidence of a divine designer or is instead just another humdrum part of creation. Creatures evolved because God wrote the script of his magnum opus so as to include them as characters within it. All features of creation-not just its most complex ones-are parts of this story even if some of them stand out to us as especially glorious. The Book of Wisdom glories in the reality that God's wisdom "reaches mightily from one end of the earth to the other, and she orders all things well" (Wis $8: 1)$. God's providence is the cause of every single detail of the universe, just as Shakespeare was responsible for every syllable of Hamlet. God orders all things in creation: the motoring of the bacterial flagellum, the vision of the 
eye, the falling of a sparrow, the hairs of your head, and the very neurons firing in your brain right now that allow you to pursue these considerations. Things like these, which most of us consider rather dull and routine, have evolved through natural processes at the behest of God's will in order to manifest his glory in the universe.

Evolutionary science indicates that these and other such features of the world have arisen naturally rather than by dint of miracles, yet does this make it any less amazing that they play the integral role they do in the world? Submitting that evolution simply is God's grand design for creating life, biologist Dennis Venema suggests that God using "natural" mechanisms to fill his creation with biodiversity does not make him any less a creator than if he had done so miraculously. Indeed, Venema contends against the tendency within ID and contemporary atheism to view God as a demiurge, " $[\mathrm{M}]$ aking an object that can self-assemble would require a design far superior to that of an object that requires manual assembly. Rather than suggesting that a self-assembling object was evidence that a designer was not needed, we would be convinced that a powerful intellect was behind it” (McKnight and Venema 2017, 89-90). Cast in terms of our analogy of creation as God's story or play, we may therefore ask: is the Lord any less the masterpiece author of creation's script just because his work takes place largely behind the scenes rather than as a character on creation's stage ${ }^{10}$

\section{Conclusion}

A Ratzingerian approach to evolutionary creation affirms a creator whose work is best described as a melody, symphony, play, or story. The divine

10 While I find this to be an incredibly valuable analogy, like all analogies this one too has an obvious limitation: God eventually does appear in the events of salvation history, culminating in the life and ministry of Jesus Christ. The framework I am developing here does not deny this but rather assumes it, along with the traditional Christian belief that God can act directly in his creation at any time through a miracle should he so choose. What I am trying to capture with this analogy is the reality that God is ever present as the cause of all creaturely causes as he moves them to their actions through the natures he has bestowed upon them. As I have attempted to show, Benedict's view is that God guides the natural processes of evolution in this way rather than stepping into his play to act as one cause among many on the world's stage. 
author who has composed a script that resolves naturally in a way consonant with the story of creation's own terms, following its own internal rules. This a story in which one which does not need to seek God only in the extraordinary but precisely in the daily workings of his providential plan that has been unfolding for billions of years. It is a script which, while entirely proceeding from the mind of its divine author, is not a static product crafted from a blueprint that develops along predictable lines. Instead, it is a dynamic universe whose outcomes are in large part contingent upon its characters who exercise true causality in their world-characters who would not even be able to exist if not for the pen of the author who created them, continually maintains them in existence, and gives each the ability to make its unique contribution to creation's plot. While this analogy too ultimately has its limits, it is as close as I have been able to get to an image that does justice to Ratzinger's fundamental insights into how God's causality operates within evolution.

Like a good many Christians at large, we may sympathize the ID movement's quest to find God's hand directly operative in specific structures within creation, yet we have seen that a significant area of divergence between ID and Ratzinger's approach to creation lies in the level at which divine design is perceived and in the role creature causality is allowed to play within the world. ID supporters look for evidence of IC at the minute biological level which in turn is thought to bespeak divine design in the cosmos. Ratzinger, on the other hand, wisely prescinds from these details, focusing his attention instead on how God's hand is operative as his masterpiece plot unfolds in the universe as a whole. Given the analysis presented here, the ID project is ultimately a misguided distraction from the real pressing questions that stand before us at the intersection of faith and evolutionary science that I have not been able to address here. I am currently exploring some of these in what will be a book-length treatment of Ratzinger's approach to creation and human origins. This article, however, has focused simply on mining the insights of the emeritus pontiff in the effort to lay out a proper understanding of how divine causality operates within the evolutionary process and in our lives today. 


\section{References}

Aquinas, Thomas. 1981. Summa Theologiae. Translated by the Fathers of the English Dominican Province. Westminster, MD.: Christian Classics.

Austriaco, Nicanor, O.P. et al. 2019. Thomistic Evolution: A Catholic Approach to Understanding Evolution in the Light of Faith. $2^{\text {nd }}$ edition. Tacoma, WA: Cluny Media.

Barr, Stephen. 2016. The Believing Scientist: Essays on Science and Religion. Grand Rapids, MI: Eerdmans.

Behe, Michael. 1996. Darwin's Black Box: The Biochemical Challenge to Evolution. New York: Free Press.

Benedict XVI. 2008. Creation and Evolution: A Conference with Pope Benedict XVI in Castel Gandolfo. Edited by Stephan Horn. San Francisco: Ignatius Press.

Catechism of the Catholic Church. 1994. Translated by United States Conference of Catholic Bishops. Washington, DC: Libreria Editrice Vaticana.

Dawkins, Richard. 2009. The Greatest Show on Earth: The Evidence for Evolution. New York: Free Press.

Dembski, William. 204. The Design Revolution: Answering the Toughest Questions about Intelligent Design. Nottingham, UK: Inter-Varsity Press.

Dodds, Michael, O.P. 2017. Unlocking Divine Action: Contemporary Science and Thomas Aquinas. Washington, DC: Catholic University of America Press.

Favale, Abigail. 2018. “Does Darwinian Evolution Petrify God's Image?,” University of Notre Dame Church Life Journal. https://churchlifejournal.nd.edu/articles/ does-darwinian-evolution-naturally-petrify-the-image-of-god/

de Gaál, Emery. 2019. “Mariology as Christology and Ecclesiology: Professor Joseph Ratzinger's Only Mariology Course.” In Joseph Ratzinger and the Healing of Reformation-Era Divisions, edited by Emery de Gaál and Matthew Levering, 93-120. Steubenville, OH: Emmaus Academic.

International Theological Commission. 2004. Communion and Stewardship. http:// www.vatican.va/roman_curia/congregations/cfaith/cti_documents/rc_con_cfaith_ doc_20040723_communion-stewardship_en.html

McKnight, Scot and Dennis Venema. 2017. Adam and the Genome: Reading Scripture after Genetic Science. Grand Rapids, MI: Brazos Press.

Meyer, Stephen. 2009. Signature in the Cell: DNA and the Evidence for Intelligent Design. New York: HarperOne.

Ratzinger, Joseph. 1958. Schöpfungslehre [unpublished Freising lecture notes]. Ratzinger, Joseph. 1964. Schöpfungslehre [unpublished Münster lecture notes]. Ratzinger, Joseph. 1976. Schöpfungslehre [unpublished Regensburg lecture notes]. 
Ratzinger, Joseph. 1973. “Schöpfungsglaube und Evolutionstheorie.” In Dogma Und Verkündigung, 147-60. Munich: Erich Wewel Verlag.

Ratzinger, Joseph. 1989. “Der Mensch zwischen Reproduktion and Schöpfung: Theologische Fragen zum Ursprung menschlichen Leben,” Internationale Katholische Zeitschrift Communio 18: 61-71.

Ratzinger, Joseph. 2002. God and the World. San Francisco: Ignatius Press.

Ratzinger, Joseph. 2005. Der Gott des Glaubens und der Gott der Philosophen: Ein Beitrag zum Problem der theologia naturalis. Edited by Heino Sonnemans. Leutesdorf: Johannes Verlag.

Ratzinger, Joseph. 2011. "Belief in Creation and the Theory of Evolution.” In Dogma and Preaching, 131-42. San Francisco: Ignatius Press.

Ratzinger, Joseph. 2013. "Man between Reproduction and Creation: Theological Questions on the Origin of Human Life.” In Joseph Ratzinger in Communio: Anthropology and Culture, vol. 2, 70-83. Grand Rapids: Eerdmans.

Sanz, Santiago. 2014. “Joseph Ratzinger y la doctrina de la creación. Los apuntes de Münster,” Revista Española de Teología 74: 31-70.

Sanz, Santiago. 2014. “Joseph Ratzinger y la doctrina de la creación. Los apuntes de Münster de 1964 (II). Algunos temas fundamentales.” Revista Española de Teología 74: 201-48.

Sanz, Santiago. 2014. “Joseph Ratzinger y la doctrina de la creación. Los apuntes de Münster de 1964 (y III). Algunos temas debatidos,” Revista Española de Teología 74: 453-96.

Sanz, Santiago. "La dottrina della creazione nelle lezioni del professor Joseph Ratzinger: gli appunti di Freising (1958)," Annales theologici 30 (2016): 11-44 . Sanz, Santiago. 2016. “La dottrina della creazione nelle lezioni del professor Joseph Ratzinger: gli appunti di Regensburg (1976)," Annales theologici 30: 251-83

Tabaczek, Mariusz, O.P. 2019. "What Do God and Creatures Really Do in an Evolutionary Change? Divine Concurrence and Transformism from the Thomistic Perspective," American Catholic Philosophical Quarterly 93.3: 445-82.

White, Thomas Joseph, O.P. 2017. The Light of Christ: An Introduction to Catholicism. Washington, DC: Catholic University of America Press. 